\section{SANDIA REPORT}

\section{SAND98-1988}

Unlimited Release

Printed September 1998

\section{1} 450649-Rew Dask foE BOEFSTI, 12690

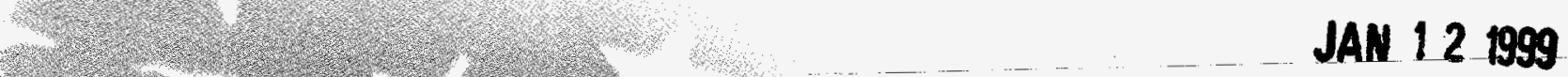 \\ Construction Costs of Six Landfill C8Jdr Designs
}

Stephen F. Dwyer

Prepared by

Sandie National Laboratories

Aibuquerque, New Mexico 87185 and Livermore, California 94550

Sandia is a multiprogram laboratory operated by Sandia Corporation, a Lockheed Martin Company, for the United States Department of Energy under Contract DE AC04-94AL 85000.

Approved for public release; further dissemination unlimited.

\section{Sandia National Laboratories}


Issued by Sandia National Laboratories, operated for the United States Department of Energy by Sandia Corporation.

NOTICE: This report was prepared as an account of work sponsored by an agency of the United States Government. Neither the United States Government nor any agency thereof, nor any of their employees, nor any of their contractors, subcontractors, or their employees, makes any warranty, express or implied, or assumes any legal liability or responsibility for the accuracy, completeness, or usefulness of any information, apparatus, product, or process disclosed, or represents that its use would not infringe privately owned rights. Reference herein to any specific commercial product, process, or service by trade name, trademark, manufacturer, or otherwise, does not necessarily constitute or imply its endorsement, recommendation, or favoring by the United States Government, any agency thereof, or any of their contractors or subcontractors. The views and opinions expressed herein do not necessarily state or reflect those of the United States Government, any agency thereof, or any of their contractors.

Printed in the United States of America. This report has been reproduced directly from the best available copy.

Available to DOE and DOE contractors from

Office of Scientific and Technical Information

P.O. Box 62

Oak Ridge, TN 37831

Prices available from (615) 576-8401, FTS 626-8401

Available to the public from

National Technical Information Service

U.S. Department of Commerce

5285 Port Royal Rd

Springfield, VA 22161

NTIS price codes

Printed copy: A03

Microfiche copy: A01

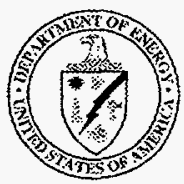




\section{DISCLAIMER}

Portions of this document may be illegible in electronic image products. Images are produced from the best available original document. 
SAND98-1988

Unlimited Release

Printed September 1998

\title{
Construction Costs of Six Landfill Cover Designs
}

\author{
Stephen F. Dwyer \\ Environmental Restoration Technology Department \\ Sandia National Laboratories \\ P.O. Box 5800 \\ Albuquerque, NM 87185-0719
}

\begin{abstract}
A large-scale field demonstration comparing and contrasting final landfill cover designs has been constructed and is currently being monitored. Four alternative cover designs and two conventional designs (a RCRA Subtitle ' $D$ ' Soil Cover and a RCRA Subtitle ' $C$ ' Compacted Clay Cover) were constructed side-by-side for direct comparison. The demonstration is intended to evaluate the various cover designs based on their respective water balance performance, ease and reliability of construction, and cost. This paper provides an overview of the construction costs of each cover design.
\end{abstract}




\section{Engineering Background}

The US Department of Energy (DOE) is in the midst of a major clean-up effort of their facilities that is expected to cost billions of dollars. These cost estimates; however, are based on "state-of-the-art" technologies, of which many are inadequate. Consequently, work has begun on the development or improvement of environmental restoration and management technologies. One particular area being researched is landfill covers. As part of their ongoing environmental restoration activities, the DOE has many radioactive, hazardous, mixed waste, and sanitary landfills to be closed in the near future. These sites, as well as mine and mill tailings piles and surface impoundments, all require either remediation to a 'clean site' status or capping with an engineered cover upon closure (Hakonson et al., 1994). Additionally, engineered covers are being considered as an interim measure to be placed on contaminated sites until they can be remediated. The Alternative Landfill Cover Demonstration (ALCD) is a largescale field test at Sandia National Laboratories, located on Kirtland Air Force Base in Albuquerque, New Mexico. Its intent is to compare and document the performance of alternative landfill cover technologies of various costs and complexities for interim stabilization and/or final closure of landfills in arid and semi-arid environments. The test covers are constructed side-by-side for direct comparison based on their performance, cost, and ease of construction. The ALCD is not intended to showcase any one particular cover system. The focus of this project is to provide the necessary tools; i.e., cost, construction and performance data, to the public and regulatory agencies so that design engineers will have less expensive, regulatory acceptable alternatives to the conventional cover designs.

The test covers are each $13 \mathrm{~m}$ wide by $100 \mathrm{~m}$ long. The $100 \mathrm{~m}$ dimension was chosen because it is representative of hazardous and mixed waste landfills found throughout the DOE complex (approximately 2 acres in surface area). All covers were constructed with a 5\% slope in all layers. The slope lengths are 50 $\mathrm{m}$ each (100 m length crowned at the middle with half of the length - $50 \mathrm{~m}$ - sloping to the east and the other half toward the west). The western slope is monitored under ambient conditions (passive monitoring). A sprinkler system was installed in the eastern slope of each cover to facilitate stress testing of the covers (active monitoring).

Continuous water balance and meteorological data is currently being obtained. It will be actively collected for a minimum five-year post construction period. In addition, periodic measurements of vegetation cover, biomass, leaf area index, and species composition are being taken.

\section{General Costs of Construction}

The covers were independently designed. The designs were packaged into a set of construction bid documents that included drawings and specifications for each test cover. The covers were divided into two separate bid packages. Preparation of these bid packages including design was not included in the costs of the covers presented in this paper. Phase I was bid in FY95 while Phase II, due to funding constraints, was bid in FY96. The phase I covers built in FY95 include a conventional RCRA Subtitle 'D' Soil Cover, a conventional RCRA Subtitle 'C' Compacted Clay Cover, and the Geosynthetic Clay Liner (GCL) Cover. The phase II covers built in FY96 include the Capillary Barrier, Anisotropic Barrier, and Evapotranspiration (ET) Cover.

Each phase of construction was competitively bid with the low bidder receiving a firm fixed price contract. The costs to construct each cover design were broken out of the overall contract with the help of the general contractor and applicable subcontractors. The entire process including the bid package preparation, bid 
process, contract award, and construction activities were performed similar to that on an actual landfill cover project.

Costs for each cover design were developed as follows: (1) common costs such as mobilizing, demobilizing, and subgrade preparation were evenly assessed to each cover; (2) all other costs such as materials and labor were carefully allocated to each cover design. A summary of the cost per surface square meter for each cover is presented in figure 7. A detailed break down of costs for each respective cover is presented in Attachment A.

\section{Conventional EPA Landfill Covers}

Two conventional cover designs were installed to provide a baseline for comparison of the alternative cover designs. Conventional Test Cover 1 (Figure 1) is a basic Soil Cover that is typically installed over sanitary municipal landfills. This cover design meets minimum requirements set forth for RCRA Subtitle ' $D$ ' governed landfills (US Dept. of Energy, 1993). This cover is $60 \mathrm{~cm}$ thick. It is constructed of essentially two layers. The bottom layer is a $45 \mathrm{~cm}$ thick compacted soil barrier layer. Only native soil was used in this layer. The soil was compacted 'wet of optimum' to $95 \%$ of maximum dry density. The soil was placed as specified to meet the maximum $1 \times 10^{-5} \mathrm{~cm} / \mathrm{sec}$ saturated hydraulic conductivity requirement of Subtitle ' $D$ ' regulated facilities. The top vegetation layer is $15 \mathrm{~cm}$ of topsoil loosely laid. This layer provides for vegetation growth and erosion protection.

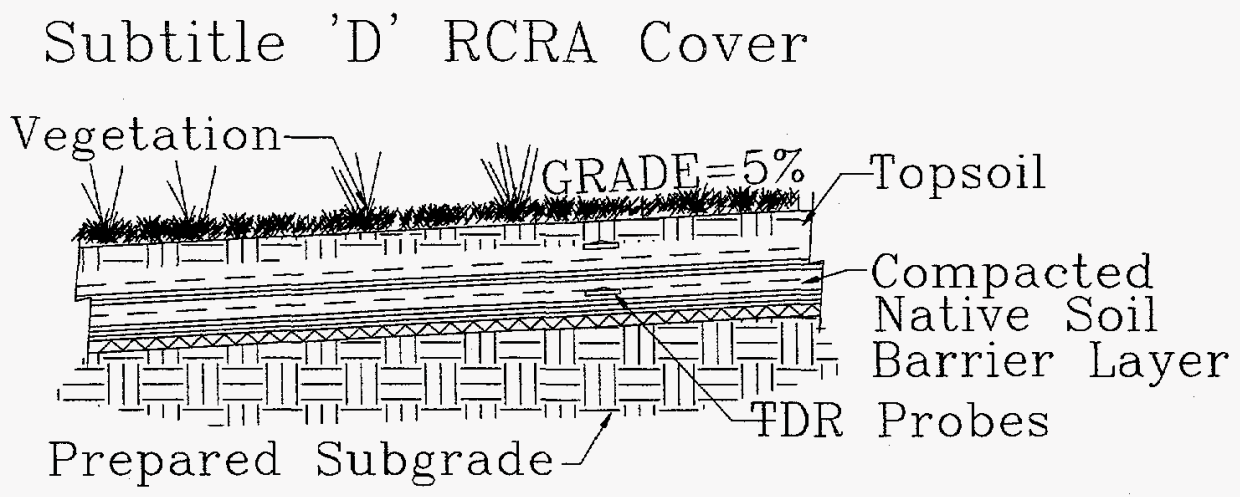

Figure 1. Conventional Test Cover 1

The Soil Cover was the simplest and least expensive of all of the covers installed. The majority of the costs include obtaining and placing the $60 \mathrm{~cm}$ thick fill soil. The bottom $45 \mathrm{~cm}$ barrier soil layer required compaction. This barrier layer was installed in three $15 \mathrm{~cm}$ compacted lift depths. Compaction was relatively easily achieved using a vibratory compactor. The cost of construction for this cover design was $\$ 51.40$ per square meter. The largest potential variability in cost for this design will be with obtaining the fill soil. If acceptable on-site soil can be used from a nearby borrow pit with little pretreatment, a substantial cost savings would be obtained compared to purchasing the fill and having it trucked on-site.

This cover, however, is generally considered inadequate at controlling infiltration into the underlying waste it is designed to isolate from the surrounding environment. An EPA sponsored study revealed that a large percentage of landfills utilizing this cover design have failed (US Environmental Protection Agency, 1988). 
Conventional Test Cover 2 (Figure 2) is a Compacted Clay Cover that is generally installed over hazardous waste landfills. This cover was designed and installed to meet minimum requirements set forth for RCRA Subtitle 'C' regulated landfills (EPA, 1991). It is $1.5 \mathrm{~m}$ thick. The typical profile for this cover consists of three layers. The bottom layer is a $60 \mathrm{~cm}$ thick barrier layer. The barrier layer's primary purpose is to prevent the downward movement of water into underlying waste. Laboratory tests revealed that the native soil required amendment to meet the saturated hydraulic conductivity requirement (maximum of $1 \times 10^{-7}$ $\mathrm{cm} / \mathrm{sec}$ ). It was constructed of native soil mixed with $6 \%$ bentonite by weight. The lifts were compacted to a minimum of $98 \%$ of maximum dry density (ASTM D698). During fill and compaction, the soil was kept at a water content 'wet of optimum' so as to remold the soil. The combination of the compaction requirements, soil amendment, and placement ('wet of optimum') was necessary to yield a maximum hydraulic conductivity of $1 \times 10^{-7} \mathrm{~cm} / \mathrm{sec}$. Constructing the barrier layer was very difficult. The most economical means of obtaining the bentonite was having it trucked in from Wyoming. It arrived in two-ton bags. The bentonite was then evenly mixed with the soil prior to its installation in the cover. The purchase and mixing of this bentonite into the soil increased the cost of the cover by $14 \%$ versus using unamended soil. After mixing, the amended soil was wetted, placed on the cover and compacted. The moist amended soil proved to be much more difficult to work with than the plain native soil. It was sticky to spread and slippery to drive on. The compaction was extremely difficult to achieve. It was compacted in four approximately $15 \mathrm{~cm}$ compacted depth lifts. Each lift in the barrier layer took about three times more effort to achieve compaction requirements than did the lifts in Conventional Test Cover 1. Substantial quality control was required to ensure the material and placement was as specified.

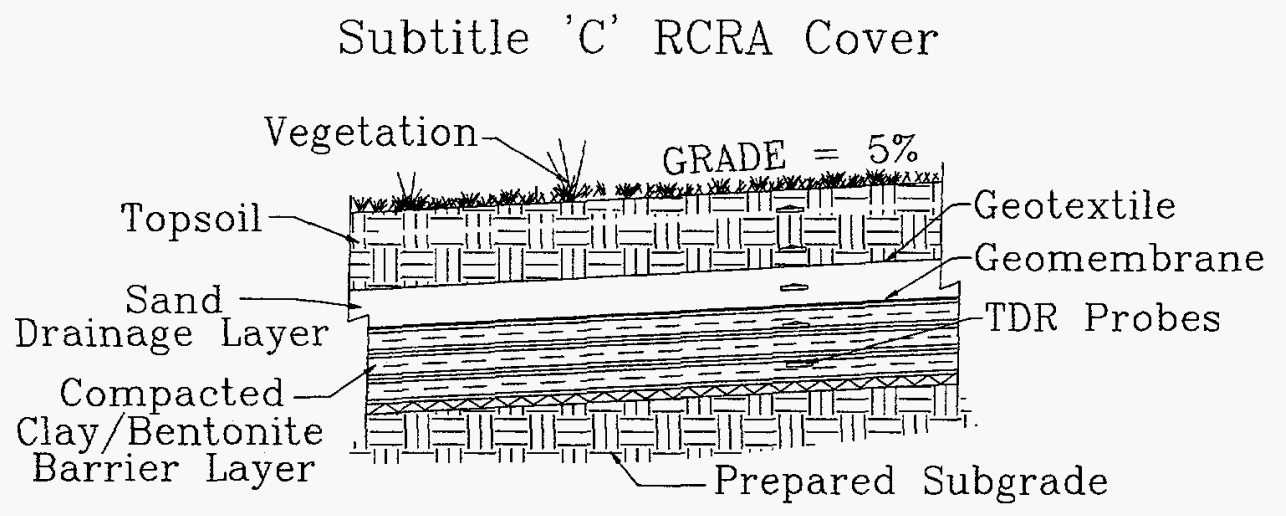

Figure 2. Conventional Test Cover 2

A 40 mil linear low density polyethylene geomembrane was placed directly on top of the clay barrier layer. The surface of the clay barrier layer was smooth-roll compacted and prepared to allow for intimate contact between it and the under-surface of the geomembrane to essentially obtain a composite barrier layer. The geomembrane was purchased and trucked to the site. The cost of the geomembrane includes not only the material cost but shipping costs. It can get very expensive for a small project if a partial load is shipped rather than a full load because the full cost of that truck's time and mileage will be billed to that shipment. This is true for all geosynthetics used. On this project, we were able to have full loads shipped. The installation of the geomembrane required spreading it in place and heat welding the seams. All seams were tested for adequacy. Any and all defects found in the geomembrane were patched and tested for adequacy. The total installed cost for the geomembrane was about $\$ 10.12$ per square meter ( $\$ 0.94$ per square foot).

The middle layer is a $30 \mathrm{~cm}$ thick drainage layer. The primary purpose of the drainage layer is to quickly route any water that has passed through the vegetation layer laterally to collection drains normally located at 
the perimeter of the landfill. This layer was constructed of sand placed directly on the geomembrane. The average hydraulic conductivity of the sand installed was $1 \times 10^{-1} \mathrm{~cm} / \mathrm{sec}$ which is an order of magnitude better than the minimum $1 \times 10^{-2} \mathrm{~cm} / \mathrm{sec}$ called for in Subtitle ' $\mathrm{C}$ '. It was trucked to the site and spread in place in a single lift. The sand used was a common material called washed concrete sand. Its cost from the supplier was about $\$ 7.70$ per ton.

A nonwoven polyester needlepunched geotextile was placed directly on top of the sand drainage layer. This served as a filter between the drainage layer material and top layer. The rolls of geotextile were placed on the sand and rolled into place. Joints were simply overlapped; no physical seaming was performed. This geotextile was installed at a cost of about $\$ 3$ per square meter $(\$ 0.28$ per square foot).

The top layer is a $60 \mathrm{~cm}$ thick vegetation layer comprised of loosely laid soil. This layer's primary purpose is to provide for vegetation growth, erosion protection, and protect the underlying layers from such events as harmful freeze/thaw cycles. It allows for storage of infiltrated water that can later be evaporated. It is 45 $\mathrm{cm}$ of native soil covered by $15 \mathrm{~cm}$ of topsoil.

The Compacted Clay Cover was by far the most difficult and expensive test cover to install. Its construction cost amounted to $\$ 157.54$ per square meter.

\section{Alternative Designs}

Any and all compaction of soil in the alternative designs was compacted 'dry of optimum' rather than 'wet of optimum' as currently recommended with the conventional covers (EPA, 1993). This was done in an effort to mitigate the potential for desiccation cracking.

Alternative Test Cover 1 (Figure 3) is a Geosynthetic Clay Cover identical to the conventional compacted clay cover with the exception that the problematic clay barrier layer was replaced with a manufactured sheet, a geosynthetic clay liner (GCL), installed in its place.

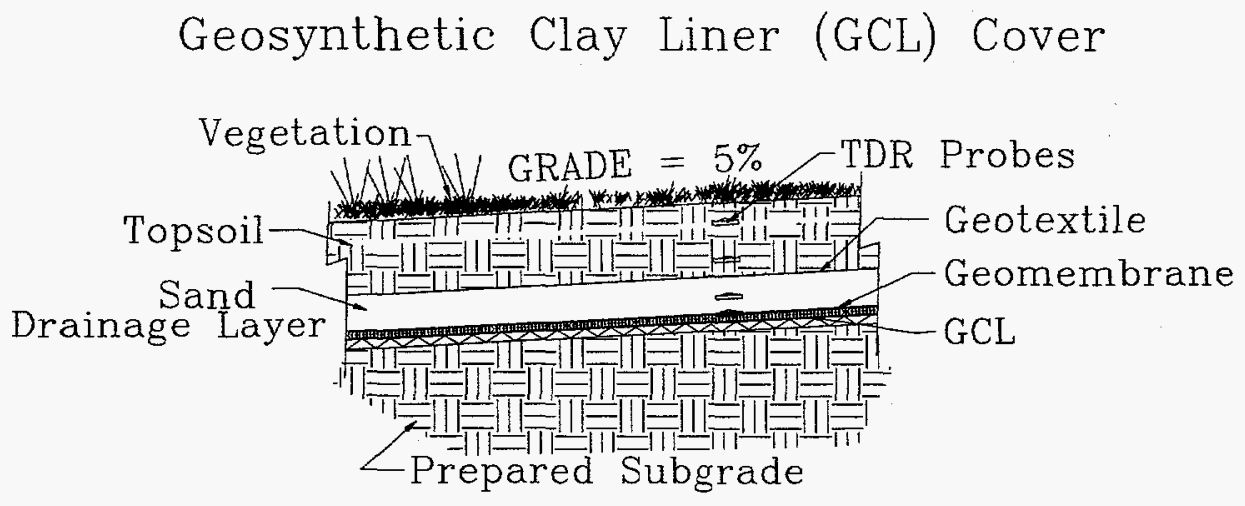

Figure 3. Alternative Test Cover 1

The GCL is the bottom barrier layer covered with a geomembrane, drainage layer and vegetation layer, respectively. The GCL sheet installed is a composite of two nonwoven fabrics sandwiching a layer of bentonite. The hydraulic conductivity of the GCL is $5 \times 10^{-9} \mathrm{~cm} / \mathrm{sec}$. 
Replacing the $60 \mathrm{~cm}$ thick clay (amended soil) barrier layer with a GCL drastically reduced the cost and difficulty of construction. The GCL was purchased and trucked to the site. The rolls were simply rolled into place. Joints were overlapped with no physical seaming. Most of the cost difference between this cover and that of the Conventional Test Cover 2 is the savings gained by installing a GCL rather than a 2 foot thick compacted clay layer. Other related savings comes from reduced construction time and thus reduced job overhead expenses as well as less job foremen and survey crew time. The topsoil, sand drainage layer, geotextile, and geomembrane were installed similarly to that in the Compacted Clay Cover. The construction cost of this cover design was $\$ 89.99$ per square meter.

Alternative Test Cover 2 (Figure 4) is a Capillary Barrier. The Capillary Barrier comprised of a finegrained layer of soil placed over a coarse-grained layer emphasizes a sufficient contrast between the hydraulic conductivity's of the fine-grained layer versus the coarse-grained layer. This contrast lends to the effect that flow through the cover is greatly slowed under unsaturated conditions.

This cover system consists of 4 primary layers: (1) a surface or topsoil layer; (2) an upper drainage layer; (3) a barrier soil layer; and (4) a lower drainage layer. The topsoil layer is $30 \mathrm{~cm}$ thick. This surface layer is placed to enhance evapotranspiration, protect against desiccation of the barrier soil layer, and provide a medium for growth of vegetation. This vegetation increases evapotranspiration and protects against surface erosion. The upper lateral drainage layer is $22 \mathrm{~cm}$ of gravel overlain by $8 \mathrm{~cm}$ of sand. The sand serves as a graded filter to prevent topsoil from clogging the drainage layer. The gravel allows for lateral drainage of any water that has percolated through the topsoil. The barrier soil layer and lower drainage layer comprise the capillary barrier. The barrier soil layer is compacted soil $45 \mathrm{~cm}$ thick. The lower drainage layer is 30 $\mathrm{cm}$ of sand.

\section{Capillary Barrier}

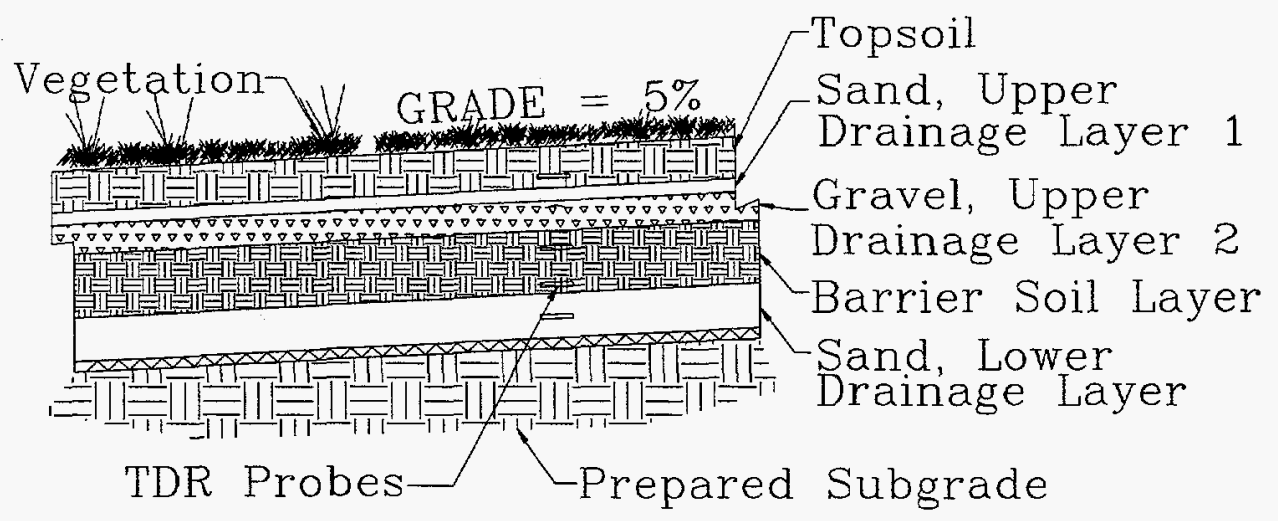

Figure 4. Alternative Test Cover 2

The Capillary Barrier was installed without any geosynthetic materials. The lower sand drainage layer is washed concrete sand. It was placed in one lift. The barrier soil layer was then placed on the sand. The first lift of the soil had to be carefully placed so as to keep a smooth uniform transition between the soil and sand. In order to minimize weight and thus not disturb the interface between the soil and sand, a small bulldozer with steel tracks was used to spread the soil. This took longer than using larger equipment with rubber tires and was slightly more expensive. The soil was placed in three $15 \mathrm{~cm}$ deep lifts. Compaction was relatively easily achieved. It was compacted to a minimum of $95 \%$ of maximum dry density. The gravel upper drainage layer was then placed in one lift. It was clean pea gravel, a readily available material. A sand upper drainage layer was then placed in one lift on the gravel. Again, special care was required to keep a smooth interface between the sand and gravel. The small bulldozer 
was again used to spread the sand into place. The $8 \mathrm{~cm}$ thick layer of sand called for in the design proved impractical. Fifteen $\mathrm{cm}$ of sand seemed to be the thinnest practical depth. The construction cost of this cover design was $\$ 92.64$ per square meter.

Alternative Test Cover 3 (Figure 5) is referred to as the Anisotropic Barrier. The design of the Anisotropic Barrier attempts to limit downward movement of water while encouraging lateral movement of water. This cover is composed of a layering of capillary barriers. The various layers are enhanced by varying soil properties and compaction techniques that lead to the anisotropic properties of the cover.

\section{Anisotropic Barrier}

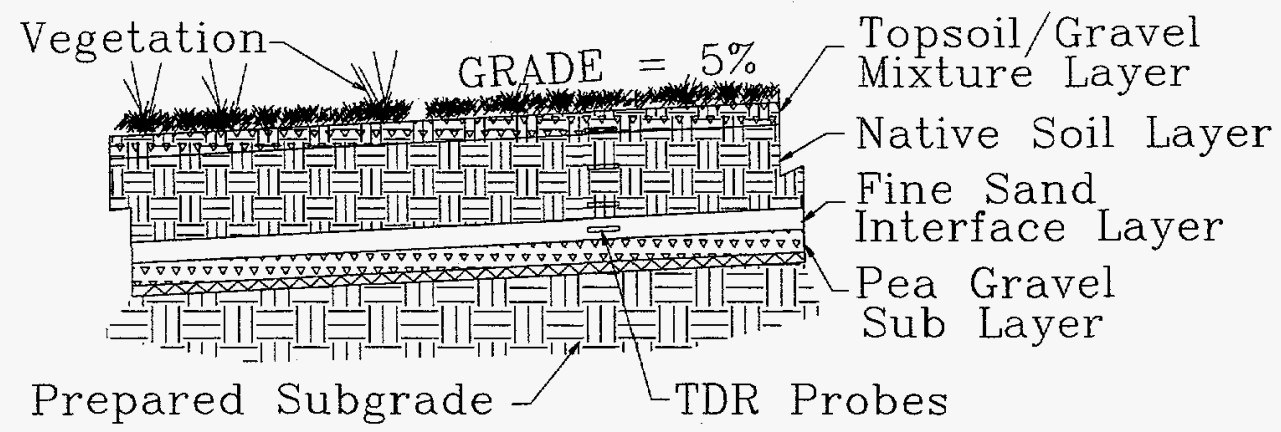

Figure 5. Alternative Test Cover 3

This cover system consists of 4 layers: (1) a top vegetation layer; (2) a cover soil layer; (3) an interface layer; and (4) a sublayer. The vegetation layer is $15 \mathrm{~cm}$ thick. It is comprised of a mixture of local topsoil and pea gravel. The gravel to soil mixture by weight was $25 \%$. This layer encourages evapotranspiration, allows for vegetation growth, and reduces surface erosion. The cover soil layer is $60 \mathrm{~cm}$ of native soil. Its function is to allow for water storage and eventual evapotranspiration, as well as, serve as a rooting medium. The interface layer is $15 \mathrm{~cm}$ of fine sand. This layer serves as a filter between the overlying soil and the underlying gravel. It also serves as a drainage layer to laterally divert water that has percolated through the cover soil. The sublayer is $15 \mathrm{~cm}$ of pea gravel. It serves as a capillary break. The interface layer and sublayer combined also serve a dual purpose as bio-barriers.

The Anisotropic Barrier was installed without any geosynthetic materials. The pea gravel sublayer was installed in one lift. The same clean pea gravel as that used on the Capillary Barrier was used on this cover. The sand interface layer was installed in one lift by the small steel tracked bulldozer to maintain the clean interface between the sand and gravel. The sand was also washed concrete sand. The native soil layer was then installed in one lift on the sand. It was also spread with the small bulldozer. The only compaction on this soil layer was due to equipment traffic on it during construction. The topsoil/gravel layer was mixed adjacent to the cover then trucked on and spread in one lift. The gravel used was clean pea gravel. The construction cost of this cover design was $\$ 75.26$ per square meter.

Alternative Test Cover 4 (Figure 6) is referred to as an Evapotranspiration (ET) Cover. The ET Cover is a soil cover with an engineered vegetative covering. This cover encourages water storage and enhances ET. It is $90 \mathrm{~cm}$ thick. The bottom $75 \mathrm{~cm}$ was compacted while the top $15 \mathrm{~cm}$ of topsoil was loosely placed. The soil allows for water storage, which when combined with the vegetation will increase, evapotranspiration. A thin layer of gravel was then spread on the surface. This layer is about an inch thick and serves to reduce surface erosion and provide for better vegetation establishment. 


\section{Evapotranspiration Soil Cover}

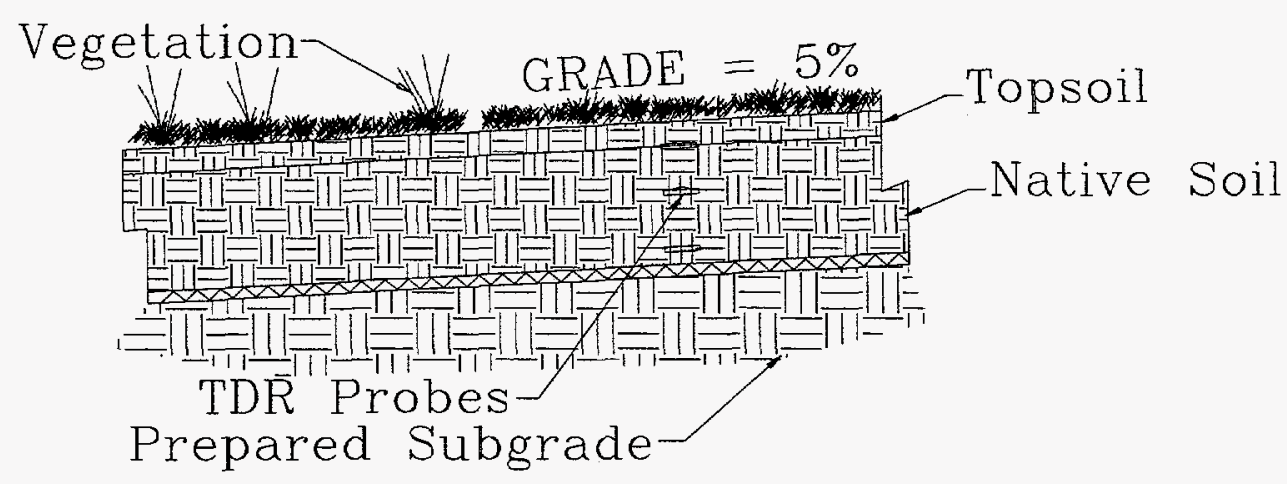

Figure 6. Alternative Cover 4

The ET Cover was constructed similarly to the RCRA Subtitle ' $D$ ' Soil Cover. The RCRA Subtitle 'D' Soil Cover's shallow depth is one of the primary reasons for its inadequacy. Computer modeling revealed that if the depth were increased to $90 \mathrm{~cm}$ in the Albuquerque climate, this would essentially eliminate water infiltration into underlying waste. The ET Cover was easily constructed placing five 15 $\mathrm{cm}$ thick compacted depth lifts overlain by one lift of topsoil. The construction cost of this cover was $\$ 73.89$ per square meter.

\section{Alternative Acceptance}

A study (Wentz, 1989) performed by the University of North Dakota concluded that the two most important factors affecting which hazardous waste management technology are to be used are that they are regulatorally acceptable and they are less expensive than past choices.. Great effort has gone into obtaining regulatory involvement and eventual acceptance of the technologies involved in this project. Because each of the alternative designs is less expensive and easier to construct than the conventional Compacted Clay Cover and much more effective than the plain Soil Cover they should be widely accepted.

\section{Expected Benefits}

The probable outcome of this demonstration is the acceptance of alternative cover designs that are significantly less costly than conventional designs. Given the thousands of acres of buried waste sites to be covered, the payoff from this demonstration may be on the order of many millions of dollars in savings.

\section{Acknowledgments}

The work was funded by the United States Department of Energy Office of Science and Technology through the Subsurface Contaminants Focus Area. 


\section{Summary}

The construction costs for each of the six landfill cover designs is shown below in figure 7. These costs may vary depending on the size and location of the site.

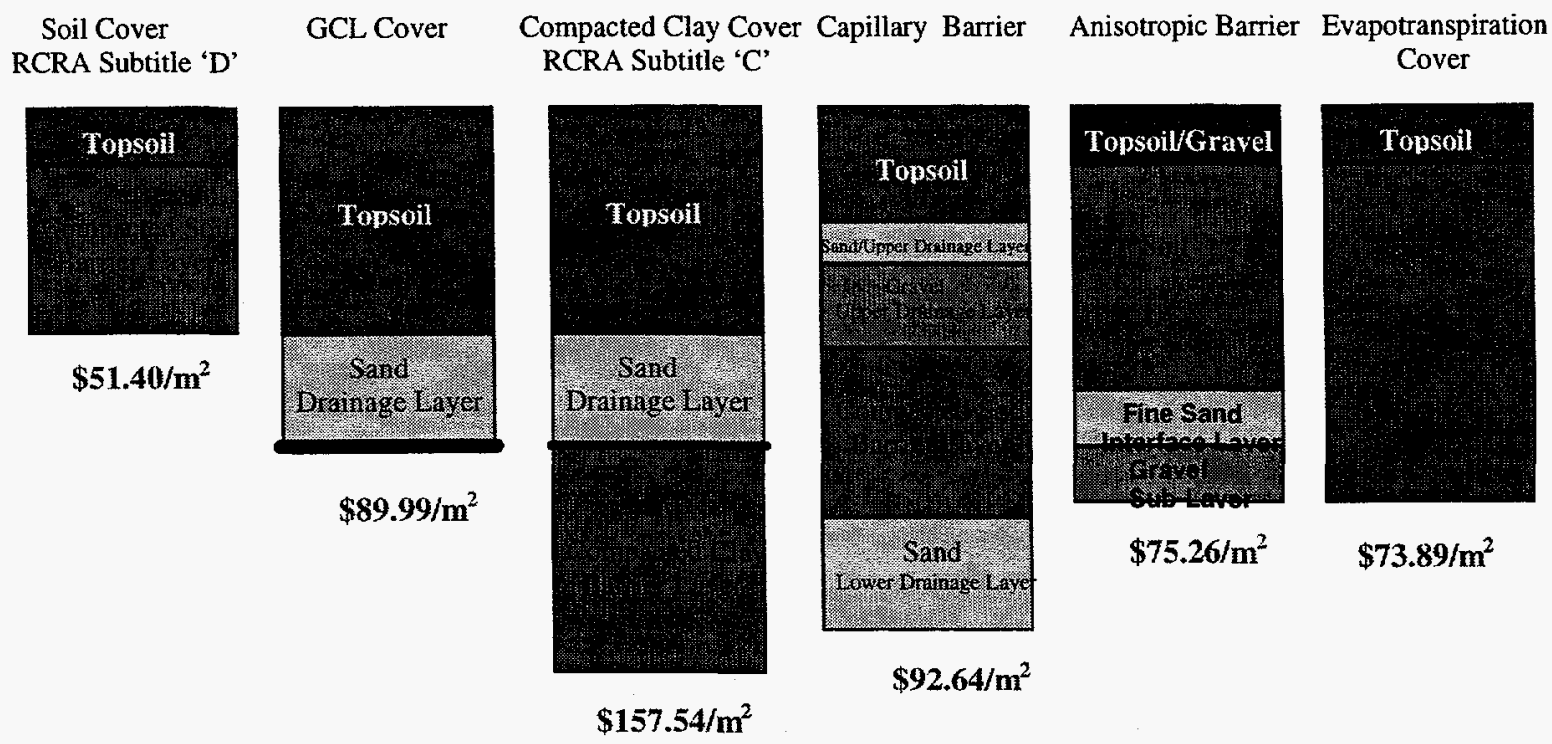

Figure 7. Summary of Construction Costs

\section{References}

1. EPA Technical Guidance Document (1993). Quality Assurance and Quality Control for Waste Containment Facilities. EPA/600/R-93/182; chapters 1 -5.

2. Hakonson et al (1994). Hydrologic Evaluation of Four Landfill Cover Designs at Hill Air Force Base, Utah. Los Alamos National Laboratories Document LA-UR-93-4469.

3. EPA Seminar Publication (1991). Design and Construction of RCRA / CERCLA Final Covers. EPA/625/4-91/025; chapters 1-7.

4. US Department of Energy - Office of Environmental Guidance, RCRA Information Brief "Closure of Municipal Solid Waste Landfills (MSWLFs)" (1993). EH-231-036/0793.

5. US Environmental Protection Agency, Office of Solid Waste (1988). Case Studies on Ground Water and Surface Water Contamination from Municipal Solid Waste Landfills. EPA/530-SW-88-040.

6. Wentz, Charles A,. (1989) Hazardous Waste Management, p.374. 


\section{Distribution}

1 AGRA Earth \& Environmental, Inc.

Attn: Ralph Gruebel

P.O. Box 1070

Carlsbad, NM 88221-1070

1 Bureau of Land Management

Attn: Brent Lewis

Denver Service Center

Building 50

Denver, CO 80225

1 Bureau of Land Management

Attn: Mike Moran

U.S. Department of Interior

Las Vegas Field Office

4765 Vegas Drive

Las Vegas, NV 89109

1 Bureau of Land Management

Attn: Stephanie Odell

Farmington District Office

1235 La Plata Highway

Farmington, NM 87401

1 CETCO

Attn: Jim Olsha

1350 W. Shure Dr.

Arlington Heights, IL 60004

1 CH2M Hill

Attn: Michael Yacyshyn

3 Hutton Center Drive

Suite 200

Santa Ana, CA 92707

1 City of Tuscon

Attn: Chris Leverenz, Disposal Administrator

Solid Waste Management Department

P.O. Box 27210

Tuscon, AZ 85726

1 Colloid Environmental Technologies Company

Attn: Bradford $\mathrm{H}$. Miller

25105 Bellota

Mission Viejo,CA 92692

1 Desert Research Institute

Attn: Glenn Wilson

755 E. Flamingo Rd.

Las Vegas, NV 89132-0040
1 Duke Engineering

Attn: Cindy Ardito

1650 University Blvd. N.E.

Albuquerque, NM 87102

1 Duke Engineering

Attn: Jim Studer

1650 University Blvd. N.E.

Albuquerque, NM 87102

1 Engineering Solutions \& Design

Attn: Jack P. Chappelle, P.E.

3916 Juan Tabo Blvd. N.E.

Albuquerque, NM 87111

1 Exxon Biomedical Sciences, Inc.

Attn: James H. Higinbotham

Mettlers Road

CN 2350

East Millstone, NJ 08875-2350

1 FERMCO

Attn: Larry Stebbins

MS: $81-2$

P.O. Box 538704

Cincinnati, $\mathrm{OH} 45235$

1 Issa Hamud

P.O. Box 527

$255 \mathrm{~N}$. Main

Logan, UT 84321

1 IT Corporation

Attn: Harlan Felt

$1425 \mathrm{~S}$. Victoria $\mathrm{Ct}$.

Suite A

San Bernadino, CA 92408

1 IT Corporation

Attn: Roy F. McKinney

5301 Central Ave., NE

Suite 700

Albuquerque, NM 87108

1 Idaho National Engineering \&

Environmental Lab

Attn: Wayne Downs

P.O. Box 1625

Idaho Falls, ID 83415 
1 Idaho National Engineering \&

Environmental Lab

Attn: Kevin Kostelnick

Lockheed Martin Idaho Technologies

P.O. Box 1625

Idaho Falls, ID 83415

1 Lawrence Livermore National Laboratory

Attn: Joe Shinn

MS L453

P.O. Box 808

Livermore, CA 94551

1 Los Alamos National Laboratory

Attn: Kay Birdsell

EES-5, MS F665

Los Alamos, NM 87545

1 Los Alamos National Laboratory

Attn: Bruce Erdal

EM-TD

MS J591

Los Alamos, NM 87545

1 Los Alamos National Laboratory

Attn: Steven Limback

ESA-EPE

MS J576

Los Alamos, NM 87545

1 Los Alamos National Laboratory

Attn: Nina Rosenberg

EES-DO

MS D446

Los Alamos, NM 87545

1 Los Alamos National Laboratory

Attn: Earl Whitney

EES-5

MS F665

Los Alamos, NM 87545

1 MDM/Lamb. Inc.

Attn: Eric Rogoff

6121 Indian School Rd., N.E.

Suite 105

Albuquerque, NM 87110

1 National Research Council

Attn: Robert Andrews, Ph.D.

National Academy of Science

Board of Radioactive Waste Mgmt.

2001 Wisconsin Ave,, N.W.

Washington, DC 20007
1 New Mexico Junior College

Attn: Pannell Library

Lovington Highway

Hobbs, NM 88240

1 New Mexico Environment Department

Attn: J. Espinosa

1190 St. Francis Drive

Santa Fe, NM 87503

1 New Mexico State Library

325 Don Gaspar

Santa Fe, NM 87503

1 New Mexico Tech

Attn: Martin Speere Memorial Library

Campus Street

Socorro, NM 87810

1 Oak Ridge National Laboratory

Attn: Tom Early

P.O. Box 2008

Oak Ridge, TN 37831

1 Oak Ridge National Laboratory

Attn: Cindy Kendrick

P.O, box 2008

Oak Ridge, TN 37831

1 SCS Engineers

Attn: Jian W. (Frank) Lliu

2702 North $44^{\text {th }}$ Street

Suite 105B

Phoenix, AZ 85008-1583

1 Sadat Associates

Attn: John Caputo

116 Village Blvd.

Princeton, NJ 08543

1 Science \& Engineering Assoc., Inc.

Attn: Bill Lowry

3205 Richards Lane

Suite A

Santa Fe, NM 87505

1 The Snow Company Inc.

Attn: Tom Snow

P.O. Box 90670

Albuquerque, NM 87199 
1 SubTerra Remedial Engineers, Inc. Attn: Andrew Murray

1820 Bering Drive

Suite 23

San Jose, CA 95112

1 Thomas Branigan Library

Attn: D. Dresp

$106 \mathrm{~W}$. Hadley St.

Las Cruces, NM 88003

1 U.S. Department of Energy

Attn: Kim Abott

Oakland Operations Office

Room $700 \mathrm{~N}$

1301 Clay Street

Oakland, CA 94612

1 U.S. Department of Energy

Attn: Richard Baker

Chicago Operations Office

9800 South Cass Ave.

Argonne, IL 60439

1 U.S. Department of Energy

Attn: Paul Beam

EM-40

Cloverleaf Building

19901 Germantown Rd.

Germantown, MD 20874

1 U.S. Department of Energy

Attn: Bob Bedick

Federal Energy Technology Center

3610 Collins Ferry Rd.

Morgantown, WV 26507

1 U.S. Department of Energy

Attn: Skip Chamberlain

EM-53

Cloverleaf Building

19901 Germantown Rd.

Germantown, MD 20874

1 U.S. Department of Energy

Attn: Michele DeGennaro

Environmental Measurements lab

201 Varick St., $5^{\text {th }}$ floor

New York, NY 10014-4811
1 U.S. Department of Energy

Attn: Gillian Eaton

Rocky Flats

Tech Site, Bldg. T124A

P.O. Box 928

Golden, $\mathrm{CO} 80402$

1 U.S. Department of Energy

Attn: John Geiger

Savannah River Operations Office

P.O. Box A

Aiken, SC 29802

$1 \quad$ U.S. Department of Energy

Attn: Dennis Green

Idaho Operations Office

850 Energy Drive

Idaho Falls, ID 83401

1 U.S. Department of Energy

Attn: Marvin Gross

Fernald Field Office

P.O. Box 538704

Cincinnati, $\mathrm{OH} 45253$

1 U.S. Department of Energy

Attn: Thomas Hicks

Savannah River Operations Office

Bldg. 703-46A

P.O. Box A

Aiken, SC 29802

1 U.S. Department of Energy

Attn: Gary Huffman

Rocky Flats Office

Highway $93^{\text {rd }} \&$ Cactus St.

Golden, CO 80402

1 U.S. Department of Energy

Attn: Sharon Johnson

Savannah River Operations Office

703 A, Rm. B202

Aiken, SC 29802

1 U.S. Department of Energy

Attn: Jeff Lenhert

Albuquerque Operations Office

P.O. Box 5400

Albuquerque, NM 87185

1 U.S. Department of Energy

Attn: Julianne Levings

Albuquerque Operations Office

P.O. Box 5400

Albuquerque, NM 87185 
1 U.S. Department of Energy

Attn: Doug Maynor

Ohio Operations Office

P.O. Box 3020

Miamisburg, $\mathrm{OH} 45343$

1 U.S. Department of Energy

Attn: Johnny Moore

Oak Ridge Operations Office

EW-923

P.O. Box 2001

Oak Ridge, TN 37831

1 U.S. Department of Energy

Attn: Chuck Morgan

Nevada Operations Office

2753 W. Highland Rd.

Las Vegas, NV 89109

1 U.S. Department of Energy

Attn: Scott McMullin

Savannah River Operations Office

P.O. Box A

Aiken,, SC 29802

1 U.S. Department of Energy

Attn: James Paulson

Chicago Operations Office

9800 South Cass Ave.

Argonne, IL 60439

1 U.S. Department of Energy

Attn: Dale Pflug

Chicago Operations Office

9800 South Cass Ave.

Argonne, IL 60439

1 U.S. Department of Energy

Attn: Elizabeth Phillips

Oak Ridge Operations Office

P.O. Box 2001

Oak Ridge, TN 37830

1 U.S. Department of Energy Attn: Elisabeth Reber-Cox Oakland Operations Office

Room $700 \mathrm{~N}$

301 Clay Street

Oakland, CA 94612

1. U.S. Department of Energy

Attn: Shannon Saget

Richland Operations Office

P.O. Box 550, K8-50

Richland, WA 99352
1 U.S. Department of Energy

Attn: Pam Saxman

Albuquerque Operations Office

P.O. Box 5400

Albuquerque, NM 87185

1 U.S. Department of Energy

Attn: George Schneider

Idaho Operations Office

785 DOE Place

Idaho Falls, ID 83402

1 U.S. Department of Energy

Attn: Mel Shupe

Federal Energy Technology Center

Industrial Park

P.O. Box 3462

Butte, MT 59702

1 U.S. Department of Energy

Attn: Helen Stolz

Nevada

P.O. Box 98518

Las Vegas, NV 89193

1 U.S. Department of Energy Attn: Maria Vargas

Richland Operations Office

P.O. Box 550

Richland, WA 99352

1 U.S. Department of Energy

Attn: Jef Walker

EM-53

Cloverleaf Bldg.

19901 Germantown Rd.

Germantown, MD 20874

1 U. S. Department of Energy

Attn: Jody Wangh

Grand Junction Office

2597 B 3/4 Road

Grand Junction, CO 81503

1 U.S. Department of Energy

Attn: Rod Warner

Ohio Operations Office

P.O. Box 538705

Cincinnati, $\mathrm{OH} 45030$ 
1 U.S. Department of Energy

Attn: Phillip Washer

Savannah River Operations Office

Bldg. 773-A

P.O. Box 616

Aiken, SC 29803

1 U.S. Department of Energy

Attn: Bill Wilborn

Nevada Operations Office

2753 S. Highland Rd.

Las Vegas, NV 89109

1 U.S. Department of Energy

Attn: Thomas Williams

Idaho Operations Office

MS1219

785 DOE Pl.

Idaho Falls, ID 83402

1 U.S. Department of Energy

Attn: James Wright

Savannah River Operations Office

Bldg. 703-46A

P.O. Box A

Aiken, SC 29803

1 U.S. Department of Energy

Attn: Paul Zielinski

EM-443

Cloverleaf Bldg.

19901 Germantown Rd.

Germantown, MD 20874

1 U.S. Environmental Protection Agency

Attn: Kelly Madalinski

401 M. Street S.W.

Mail Code 51102G

Washington, DC 20460

1 U.S. Environmental Protection Agency

Attn: Arturo Palomares

Region 8

$99918^{\text {th }}$ Street

Suite 500

Denver, CO 80202

1 U.S. Environmental Protection Agency

Attn: Darryl Petker, P.E.

State of California

Integrated Waste Management Board

8800 Cal Center Drive

Sacramento, CA 95826
1 U.S. Environmental Protection Agency

Attn: Robert Shelnutt

75 Hawthorn Street. H-2-2

San Francisco, CA 94105-3901

1 U. S. Environmental Protection Agency

Attn: Ken Skahn

(5202G)

401 M Street S.W.

Washington, D.C. 20460

1 U.S. Environmental Protection Agency

Attn: Art Palomares

Region 8

$99918^{\text {th }}$ Street

Suite $500 \mathrm{MC}$ : 8EPR-F

Denver, CO . 80202-2466

1 University of New Mexico

Attn: John Stormont

Dept. of Civil Engineering

Albuquerque, NM 87131

1 University of New Mexico

Attn: Bruce Thompson

Dept. of Civil Engineering

Albuquerque, NM 87131

1 University of Texas at Austin

Attn: David Daniel

Dept. of Civil Engineering

Cockrell Hall

Room 9.102

Austin, TX 78712

1 Westinghouse Savannah River Company

Attn: Michael Serrato

Savannah River Technology Center

Environmental Sciences Section

P.O. Box 616/773-42A

Aiken, SC 29802

1 MS0701 R. W. Lynch, 6100

1 MS0719 G. C. Allen, 6131

1 MS0719 T. D. Burford, 6131

10 MS0719 S. F. Dwyer, 6131

1 MS0719 D.A. Padilla, 6131

1 MS0724 J. B. Woodard, 6000

1 MS1132 W. B. Cox, 6100

1 MS1132 R. E. Fate, 6132

1 MS1147 F. B. Nimick, 6133

1 MS1148 G. L. Peace,

2 MS0619 Review \& Approval Desk, 12690 for DOE/OSTI

2 MS0899 Technical Library, 4916

1 MS9018 Central Technical Files, 8940-2 


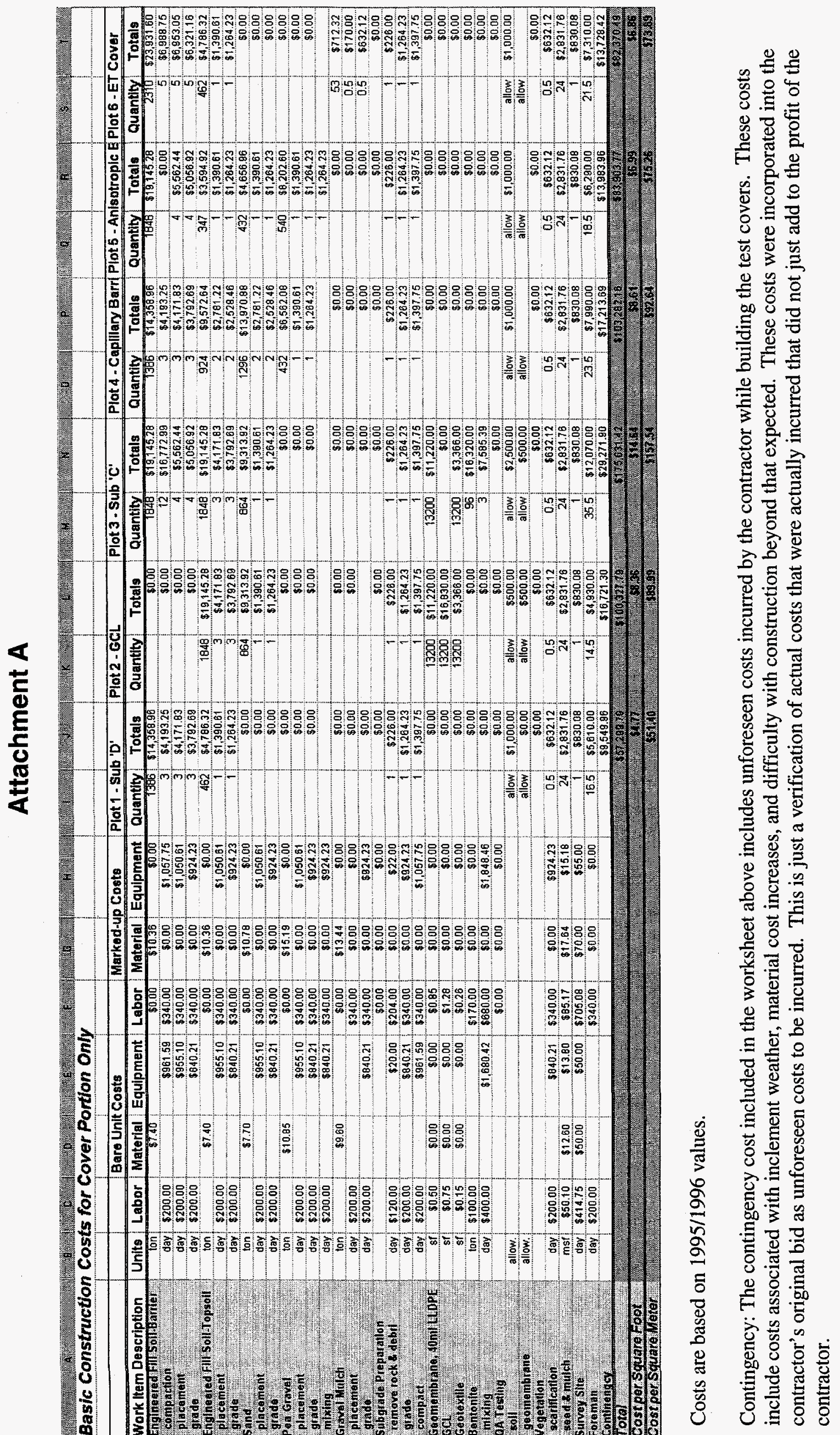

